\title{
Effect of Phosphorus and Sulphur Organo-Mineral Fertilizers on Grain Yield, Agronomic Use Efficiency and Apparent Recovery by Green Gram (Vigna radiata L.)
}

\author{
D.K. Singh ${ }^{1}$, Surendra Singh ${ }^{2}$ and Amitesh Kumar Singh ${ }^{3 *}$ \\ ${ }^{1}$ National P G College, Barahalganj, Gorakhpur, U.P., India \\ ${ }^{2}$ Department of Soil Science and Agricultural Chemistry, Institute of Agricultural Sciences, \\ Banaras Hindu University, Varanasi-221005, Utter Pradesh, India \\ ${ }^{3}$ Department of Agriculture, Ballia, U.P., India \\ *Corresponding author
}

\section{A B S T R A C T}

\begin{tabular}{|l|}
\hline Ke y w o r d s \\
$\begin{array}{l}\text { Apparent recovery, Green } \\
\text { gram, Phosphorus, } \\
\text { Sulphur, Use efficiency, } \\
\text { Yield }\end{array}$ \\
\hline Article Info \\
\hline $\begin{array}{l}\text { Accepted: } \\
\text { 04 May 2018 } \\
\text { Available Online: } \\
\text { 10 June 2018 }\end{array}$ \\
\hline
\end{tabular}

\section{Introduction}

Pulses are the basic ingredient in the diets of a vast majority of the Indian population, as they provide a perfect mix of vegetarian protein component of high biological value when supplemented with cereals. Pulses are also an excellent feed and fodder for livestock. Endowed with the unique ability of biological nitrogen fixation, carbon sequestration, soil amelioration, low water requirement and capacity to withstand harsh climate, pulses have remained an integral component of sustainable crop production system since time immemorial, especially in the dry areas. They also offer good scope for crop diversification (grow profitably in relatively low-input management conditions) and intensification (short growing period). India is the largest producer of pulses in the world, with $24 \%$ share in the global production. The important pulse crops are chickpea (48\%), pigeonpea $(15 \%)$, mungbean $(7 \%)$, urdbean $(7 \%)$, lentil (5\%) and field pea (5\%). The major pulseproducing states are Madhya Pradesh, Maharashtra, Rajasthan, Uttar Pradesh, Karnataka and Andhra Pradesh, which together account for about $80 \%$ of the total 
production. For mungbean, Uttar Pradesh (18\%), Andhra Pradesh (13\%), Madhya Pradesh (8\%) and Maharashtra (6\%) showed impressive perform in production (Ali and Gupta, 2012).

The key role of nutrient in the phenomenal growth in food production in developing countries is well established in India however, the cost of fertilizers, particularly $\mathrm{P}$ and $\mathrm{S}$ fertilizers is very high because of nonavailability of raw materials suitable for production of conventional phosphatic and sulphur fertilizers. India has large deposits of rock phosphate (RP), most of which are lowgrade and unsuitable for manufacturing of commercial P-fertilizers because of their low $\mathrm{P}$ content and low reactivity (Narayanasamy and Biswas, 1998). Rock phosphates for direct application are effective in acid soils. However, a minimum processing is required before application in non-acid soils. Some alternative methods for improving low-grade RP are by partial acidulation, thermal alteration (Reddy et al., 2000); blending with water-soluble fertilizers, dry compaction of RP with water-soluble $\mathrm{P}$ fertilizers and preparation of RP-enriched compost (Biswas and Narayanasamy, 2006).

Preparation of rock phosphate and pyrite enriched compost or $\mathrm{P} / \mathrm{S}$-organo mineral fertilizers (OMF)could be an option to improve soil quality by increasing microbial activities as well as physical and chemical properties of the soil, thereby provides better soil environment for growth and development. However, very limited information is available on preparation of organo mineral fertilizers using crop residues mixed(rice straw) with rock phosphate and pyrite along with microbial inoculation to enhance biodegradation process of organic matter as well as to improve the quality of product, an area that requires thorough investigation. Hence, it is important to develop a suitable technique for preparation of good quality of compost in the shortest possible time and evaluate its effectiveness as source of nutrients for crop production under intensive cropping system for improving soil health.

Composting is recognized as an economical and sustainable option for waste management as it is easy to undertake and can be conducted in the local site of the produce (Singh and Amberger, 1998; Biswas et al., 2009). However, traditional composts prepared from farm wastes have low nutrient content, particularly $\mathrm{P}$ and $\mathrm{S}$ and these nutrients need to be enriched. Therefore, compost may be prepared from rice straw enriched with rock phosphate and pyrite using cellulose, degrading phosphate solubilizers and sulphur dissolving microorganisms such as Trichoderma, PSB and Thiobacilli spp.

The rock phosphate (RP) and pyrite enriched compost in plant nutrition is now attracting the attention of agriculturists and soil scientists throughout the world. The cost of chemical fertilizer has increased in recent times throughout the world in general, and India in particular. Therefore, it is the need of the day to find an alternate source of phosphate and sulphate fertilizers.

Recycling of agricultural and industrial wastes for crop production is gaining in recent years because of shortage of nutrients and high cost of chemical fertilizers (Biswas, 2011). In India, around 600-700 Mt of agricultural waste is available including $250 \mathrm{Mt}$ of crop residues every year. The conversion of rice straw into value added compost may have the potential to improve productivity of the crops and reduce environmental pollution. Biswas and Narayanasamy (2006) have made to produce compost from rice straw enriched with natural mineral and bio inoculant which may serve as a supplement source of plant nutrients. 
The organo-mineral fertilizers (OMF) are a better alternative to inorganic fertilizers as it improve not only soil but also increase its organic matter content. The applications of OMF improve the physical, chemical and microbiological properties of the soil. The important role of OMF is to improve the yield and quality of different crops and enrich nutrient status of soil. Organo-mineral fertilizers (OMF) offer several advantages over organic amendments or mineral fertilizers. They improve plant-mineral interaction by reducing mineral absorption of nutrients (Patel and Thakur, 2003). The organo-mineral fertilizers in the soil provide structure and forms stable aggregates. This provides the conducive environment for the survival of living organisms. Currently many efforts are being made in order to restore fertility and productivity of soil using this technique. A good alternative of management of alluvial soils in an eco-friendly way is to use various types of organo-mineral fertilizers.

Strategies for the production and application of organo-mineral fertilizers need to be developed to optimize their agronomic performance and to minimize potential environmental risks arising from their use. It is understood that the development of OMF products constitutes a sustainable approach towards the efficient use of organic resources in agriculture. The development of OMF represents a significant technological change to the way rice straw/crop residue is currently being recycled to agriculture and it appears to be in line with current aspect to enhance the environment and soil health quality.

\section{Materials and Methods}

The field experimentation on was conducted at the Agricultural Research Farm, Institute of Agricultural Sciences, Banaras Hindu University, Varanasi during kharif season of 2013-14 and 2014-15. The sixteen treatments combination of recommendation dose of fertilizers, the level of phospho-organomineral fertilizer and two level of sulphur organo-mineral fertilizer viz. $\mathrm{T}_{1}$-Control, $\mathrm{T}_{2}$ $50 \%$ RDF, $\mathrm{T}_{3}-75 \%$ RDF, $\mathrm{T}_{4}-100 \%$ RDF, $\mathrm{T}_{5-}$ $75 \% \mathrm{RDF}+\mathrm{P}-\mathrm{OMF} @ 5.0 \mathrm{q} \mathrm{ha}^{-1}, \mathrm{~T}_{6}-75 \%$ $\mathrm{RDF}+\mathrm{S}-\mathrm{OMF} @ 5.0 \mathrm{q} \mathrm{ha}^{-1}, \mathrm{~T}_{7}-75 \% \mathrm{RDF}+$ P-OMF@5.0 q ha ${ }^{-1}+$ S-OMF @ $5.0 \mathrm{q} \mathrm{ha}^{-1}$, $\mathrm{T}_{8}-75 \%$ RDF + P-OMF @ $10.0 \mathrm{q} \mathrm{ha}^{-1}, \mathrm{~T}_{9^{-}}-75 \%$ $\mathrm{RDF}+\mathrm{S}-\mathrm{OMF} @ 10.0 \mathrm{q} \mathrm{ha}^{-1}, \mathrm{~T}_{10^{-}} 75 \% \mathrm{RDF}+$ P-OMF @10.0 q ha ${ }^{-1}+$ S-OMF @ $10.0 \mathrm{q} \mathrm{ha}^{-1}$, $\mathrm{T}_{11}-50 \% \mathrm{RDF}+\mathrm{P}-\mathrm{OMF} @ 5.0 \mathrm{q} \mathrm{ha}^{-1}, \mathrm{~T}_{12^{-}}$ $50 \% \mathrm{RDF}+\mathrm{S}-\mathrm{OMF} @ 5.0 \mathrm{q} \mathrm{ha}^{-1}, \mathrm{~T}_{13}-50 \%$ $\mathrm{RDF}+\mathrm{P}-\mathrm{OMF} @ 5.0 \mathrm{q} \mathrm{ha}{ }^{-1}+\mathrm{S}-\mathrm{OMF} @ 5.0 \mathrm{q}$ $\mathrm{ha}^{-1}, \mathrm{~T}_{14}-50 \% \mathrm{RDF}+\mathrm{S}-\mathrm{OMF} @ 10.0 \mathrm{q} \mathrm{ha}^{-1}$,

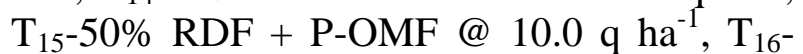
$50 \%$ RDF + P-OMF@10.0 q ha ${ }^{-1}+$ S-OMF @ $10.0 \mathrm{q} \mathrm{ha}^{-1}$. Green gram (Vigna radiata $\mathrm{L}$. Wilczek) variety HUM-12 developed at Department of Genetic and plant breeding, Institute of Agricultural Sciences, Banaras Hindu University, Varanasi was used in the study. This variety suits well in drained rainfed condition, fits in the green gramwheat cropping system of Northern India. The treatments considered of recommended dose of fertilizers (50, 75 and $100 \%$ ) individually or in combination of P-OMF and S-OMF, Organo-mineral fertilizers each@ $0.0 \mathrm{q} \mathrm{ha}^{-1}$ and10.0 $\mathrm{q} \mathrm{ha}^{-1}$ were applied in soil at the time of sowing of Green gram only. Full dose of phosphorous in the form of di-ammonium phosphate@60 kg ha ${ }^{-1}$ and potassium in the form of sulphate of potash @ $40 \mathrm{~kg} \mathrm{ha}^{-1}$ and half dose of nitrogen through urea were applied as basal dose at the time of sowing. The half dose of nitrogen was applied after first and second irrigation. All the data reported in the manuscript were analysed statically applying Randomized Block Design (RBD) by the method of "Analysis of Variance" as described by Gomez and Gomez (1984). The statistical significance of the treatment effect was judged with the help of variance ratio test. Critical Difference (C.D.) at $0.05 \%$ level of significance was worked out 
to determine the difference between treatment means.

\section{Results and Discussion}

\section{Grain yield (q ha ${ }^{-1}$ )}

Yield is a function of complex interrelationships of its components, which are determined from the growth in vegetative phase and its subsequent reflection in reproduction phase of the plant. Vigorously growing plants are able to absorb larger quantity of mineral nutrients through welldeveloped root system. Hence, grain yield is directly used for assessing the productivity of soil in different kind and rates of fertilizer applications.

The grain yield in green gram varied between 6.47 to $14.74 \mathrm{q} \mathrm{ha}^{-1}$ (Table 1 ). The maximum grain yield was also recorded with $\mathrm{T}_{16}$ (50\%RDF+ P-OMF @ $10.0 \mathrm{qha}^{-1}+\mathrm{S}-$ OMF@10.0 $\mathrm{qha}^{-1}$ ) recorded with during both the year of experiment. The minimum grain yield was observed in $T_{1}$. A valid reason for enhanced grain yield due to applied $\mathrm{P}$ and $\mathrm{S}$ organo-mineral fertilizers over out in soil. Kushwaha (2007) also found similar results that the increase in yield attributing characters and yield in higher levels of rock phosphate with PSB and their interaction with organic manures were attributed to the increased availability of phosphorus which also favoured the symbiotic $\mathrm{N}_{2}$ fixation and higher growth of plants, thereby had positive effect on yield and attributes.

\section{Biological yield (q $\left.\mathrm{ha}^{-1}\right)$ and harvest index $(\%)$}

The maximum biological yield and harvest index of green gram were and 48.53 to $30.38 \mathrm{q}$ $\mathrm{ha}^{-1}$ with application $50 \%$ RDF along with application $10 \mathrm{q} \mathrm{ha}^{-1}$ each $\mathrm{P}$ and $\mathrm{S}$ organomineral fertilizers $\left(\mathrm{T}_{16}\right)$. The minimum biological yield obtained in $20.46 \mathrm{q} \mathrm{ha}^{-1}$ (Table 1). The treatment $T_{16}, T_{10}, T_{13}$ and $T_{15}$ had significantly as per increase over the control $\left(\mathrm{T}_{1}\right)$.

There was a very close relation between the yield and its components, especially with number of grains per pods. The improved growth attributes, i.e. plant height and 1000 grain weight, might be responsible for improved yield attributes. It was found that application of $\mathrm{P}$ and $\mathrm{S}$ Organo-mineral fertilizers improved various yield parameters resulting in an increase of grain yield. Increase in yield can be ascribed to the beneficial effects of added through organic mineral fertilizers in soil. Significant increase in straw yield might be due to the availability of nutrients to the crop in sufficient amount by the organomineral fertilizers application. Significant and positive correlation existed between grain yield and some important yield attributes such as number of pods per plant, number of seeds per pod, test weight, haulm yield and provided the support for higher seed yield. The higher biological and harvest index may probably due to combined application of RDF along with organomineral fertilizers.

These results are in conformity with the findings of Yadav (2013), Saravanan and Panneerselvam (2014). The higher yields of crops obtained in enriched compost treated plots were possibly caused by other benefits of organic matter exceeding $\mathrm{P}$ and $\mathrm{S}$ supply, such as improvements in microbial activities, better supply of secondary and micronutrients, which are not supplied by $100 \%$ RDF, and lower losses of nutrients from the soil (Yadav et al., 2002; Singh, 2004).

\section{Phosphorus use efficiency}

Phosphorus use efficiency in green gram varied from 3.17 to 24.53 (kg grain $\mathrm{kg}^{-1}$ applied P). 
Table.1 Effect of phosphorus and sulphur organo-mineral fertilizers on grain, biological yield and harvest index of green gram

\begin{tabular}{|c|c|c|c|c|c|c|c|c|c|c|}
\hline \multirow[t]{2}{*}{ Treatment } & \multicolumn{4}{|c|}{ Grain $\left(\mathbf{q} \mathbf{h a}^{-1}\right)$} & \multicolumn{3}{|c|}{ Biological Yield $\left(\mathbf{q} \mathrm{ha}^{-1}\right)$} & \multicolumn{3}{|c|}{ Harvest Index (\%) } \\
\hline & 2013-14 & 2014-15 & \multicolumn{2}{|c|}{ Pooled } & 2013-14 & 2014-15 & Pooled & 2013-14 & 2014-15 & Pooled \\
\hline$\overline{T_{1}}$ & 6.41 & 6.52 & \multicolumn{2}{|c|}{6.47} & 20.19 & 20.73 & 20.46 & 31.75 & 31.45 & 31.60 \\
\hline$\overline{T_{2}}$ & 7.42 & 7.41 & \multicolumn{2}{|c|}{7.42} & 21.24 & 21.92 & 21.69 & 34.93 & 33.80 & 34.37 \\
\hline $\mathbf{T}_{3}$ & 7.51 & 7.65 & \multicolumn{2}{|c|}{7.58} & 24.76 & 24.51 & 25.32 & 30.33 & 31.21 & 30.77 \\
\hline $\mathbf{T}_{4}$ & 8.06 & 8.78 & \multicolumn{2}{|c|}{8.42} & 27.96 & 30.08 & 29.26 & 28.83 & 29.19 & 29.01 \\
\hline $\mathrm{T}_{5}$ & 8.25 & 9.14 & \multicolumn{2}{|c|}{8.70} & 28.89 & 28.87 & 28.88 & 28.56 & 31.66 & 30.11 \\
\hline$\overline{T_{6}}$ & 10.38 & 11.02 & \multicolumn{2}{|c|}{10.70} & 34.24 & 33.14 & 34.70 & 30.32 & 33.25 & 31.78 \\
\hline$\overline{\mathbf{T}_{7}}$ & 9.75 & 10.02 & \multicolumn{2}{|c|}{9.89} & 32.18 & 33.16 & 32.17 & 30.30 & 30.22 & 30.26 \\
\hline$\overline{T_{8}}$ & 10.42 & 11.20 & \multicolumn{2}{|c|}{10.81} & 33.03 & 36.16 & 34.03 & 31.55 & 30.97 & 31.26 \\
\hline $\mathrm{T}_{9}$ & 10.39 & 10.14 & \multicolumn{2}{|c|}{10.27} & 33.05 & 33.3 & 32.86 & 31.44 & 30.45 & 30.94 \\
\hline$\overline{T_{10}}$ & 10.77 & 10.78 & \multicolumn{2}{|c|}{10.78} & 34.31 & 34.97 & 34.56 & 31.39 & 30.83 & 31.11 \\
\hline$\overline{T_{11}}$ & 10.91 & 11.89 & \multicolumn{2}{|c|}{11.40} & 37.25 & 37.76 & 37.53 & 29.29 & 31.49 & 30.39 \\
\hline$\overline{T_{12}}$ & 11.62 & 11.85 & \multicolumn{2}{|c|}{11.74} & 39.6 & 38.51 & 39.06 & 29.34 & 30.77 & 30.06 \\
\hline$\overline{T_{13}}$ & 12.11 & 12.47 & \multicolumn{2}{|c|}{12.29} & 41.12 & 41.48 & 40.82 & 29.45 & 30.06 & 29.76 \\
\hline$\overline{T_{14}}$ & 13.78 & 14.03 & \multicolumn{2}{|c|}{13.91} & 46.12 & 46.25 & 45.17 & 29.88 & 30.34 & 30.11 \\
\hline$T_{15}$ & 13.41 & 13.52 & \multicolumn{2}{|c|}{13.47} & 43.16 & 47.3 & 43.55 & 31.07 & 28.58 & 29.83 \\
\hline $\mathbf{T}_{16}$ & 14.50 & 14.98 & \multicolumn{2}{|c|}{14.74} & 47.62 & 49.43 & 48.53 & 30.45 & 30.31 & 30.38 \\
\hline SEm \pm & 0.32 & 0.34 & \multicolumn{2}{|c|}{0.33} & 1.06 & 1.11 & 1.08 & 0.92 & 0.93 & 0.92 \\
\hline $\mathrm{CD}(\mathrm{P}=0.05)$ & 0.93 & 0.97 & \multicolumn{2}{|c|}{0.95} & 3.07 & 3.20 & 3.11 & 2.66 & 2.67 & 2.67 \\
\hline $\mathrm{T}_{1}$-Control & \multicolumn{3}{|c|}{$\mathrm{T}_{5-75 \% R D F+\text { P-OMF@5.0qha }}$} & \multicolumn{4}{|c|}{$\mathrm{T}_{9}-75 \% \mathrm{RDF}+\mathrm{S}-\mathrm{OMF} @ 10.0 \mathrm{qha} \mathrm{a}^{-1}$} & \multicolumn{3}{|c|}{$\begin{array}{l}\mathrm{T}_{13}-50 \% \mathrm{RDF}+\mathrm{P}-\mathrm{OMF} @ 5.0 \mathrm{qha}^{-1}+\mathrm{S}- \\
\text { OMF@5.0qha }\end{array}$} \\
\hline $\mathrm{T}_{2}-50 \% \mathrm{RDF}$ & \multicolumn{3}{|c|}{$\mathbf{T}_{6}-75 \% \mathrm{RDF}+\mathrm{S}-\mathrm{OMF} @ 5.0 \mathrm{qha}^{-1}$} & \multicolumn{4}{|c|}{$\mathbf{T}_{10}-75 \%$ RDF+P-OMF@10.0qha ${ }^{-1}+\mathrm{S}-\mathrm{OMF} @ 10.0 \mathrm{qha}^{-1}$} & \multicolumn{3}{|c|}{$\mathbf{T}_{14}-50 \% \mathrm{RDF}+\mathrm{S}-\mathrm{OMF} @ 10.0 \mathrm{qha}^{-1}$} \\
\hline $\mathrm{T}_{3}-\mathbf{7 5} \% \mathrm{RDF}$ & \multicolumn{3}{|c|}{$\begin{array}{l}\mathbf{T}_{7}-75 \% \mathrm{RDF}+\mathrm{P}-\mathrm{OMF} @ 5.0 \mathrm{qha}^{-1}+\mathrm{S}- \\
\mathrm{OMF}^{-}\end{array}$} & \multicolumn{4}{|c|}{$\mathbf{T}_{11}-50 \% \mathrm{RDF}+\mathrm{P}-\mathrm{OMF} @ 5.0 \mathrm{qha}^{-1}$} & \multicolumn{3}{|c|}{$\mathbf{T}_{15}-50 \%$ RDF+P-OMF@10.0 qha ${ }^{-1}$} \\
\hline $\begin{array}{l}\mathrm{T}_{4^{-}} \\
100 \% \mathrm{RDF}\end{array}$ & $\mathbf{T}_{8^{-}}-75 \% \mathrm{RDF}$ & MF@10.0 & & & $o \mathrm{RDF}+\mathrm{S}-\mathrm{C}$ & @ 5.0qha ${ }^{-1}$ & & $\begin{array}{l}\mathbf{T}_{16}-50 \% \\
\text { OMF@ }\end{array}$ & $\begin{array}{l}\text { P-OMF@ } \\
a^{-1}\end{array}$ & $\mathrm{ha}^{-1}+\mathrm{S}-$ \\
\hline
\end{tabular}

P-OMF-Phosphorus organo mineral fertilizer 
Table.2 Effect of phosphorus and sulphur organo-mineral fertilizers on P and S- use efficiency by green gram

\begin{tabular}{|c|c|c|c|c|c|c|}
\hline \multirow[t]{2}{*}{ Treatment } & \multicolumn{3}{|c|}{ P- use efficiency (kg grain $\mathrm{kg}^{-1}$ applied $\left.\mathrm{P}\right)$} & \multicolumn{3}{|c|}{ S- Use efficiency(kg grain $\mathrm{kg}^{-1}$ applied S) } \\
\hline & 2013-14 & 2014-15 & Pooled & 2013-14 & 2014-15 & Pooled \\
\hline $\mathbf{T}_{1}$ & 0.0 & 0.0 & 0.0 & 0.0 & 0.0 & 0.0 \\
\hline $\mathbf{T}_{2}$ & 3.37 & 2.97 & 3.17 & 14.03 & 15.01 & 14.52 \\
\hline$\overline{\mathbf{T}_{3}}$ & 2.44 & 2.51 & 2.48 & 10.38 & 11.36 & 10.87 \\
\hline $\mathbf{T}_{4}$ & 2.75 & 3.77 & 3.26 & 11.46 & 12.44 & 11.95 \\
\hline$\overline{T_{5}}$ & 3.93 & 5.59 & 4.76 & 17.36 & 18.34 & 17.85 \\
\hline$\overline{T_{6}}$ & 8.82 & 10.00 & 9.41 & 23.50 & 24.48 & 23.99 \\
\hline$\overline{\mathbf{T}_{7}}$ & 7.13 & 7.47 & 7.30 & 24.19 & 25.17 & 24.68 \\
\hline$\overline{T_{8}}$ & 8.23 & 9.60 & 8.92 & 27.83 & 28.68 & 28.255 \\
\hline $\mathrm{T}_{9}$ & 8.84 & 8.04 & 8.44 & 30.50 & 31.35 & 30.925 \\
\hline$\overline{T_{10}}$ & 8.95 & 8.74 & 8.85 & 31.41 & 32.26 & 31.835 \\
\hline$\overline{T_{11}}$ & 14.12 & 16.85 & 15.49 & 32.50 & 33.35 & 32.925 \\
\hline $\mathrm{T}_{12}$ & 17.37 & 17.77 & 17.57 & 33.73 & 34.58 & 34.155 \\
\hline $\mathbf{T}_{13}$ & 16.90 & 17.64 & 17.27 & 34.54 & 35.22 & 34.88 \\
\hline$\overline{T_{14}}$ & 21.85 & 22.27 & 22.06 & 35.36 & 36.04 & 35.7 \\
\hline $\mathbf{T}_{15}$ & 23.33 & 23.33 & 23.33 & 36.07 & 36.75 & 36.41 \\
\hline $\mathbf{T}_{16}$ & 23.98 & 25.08 & 24.53 & 37.61 & 38.29 & 37.95 \\
\hline SEm \pm & 1.06 & 1.00 & 1.03 & 0.86 & 0.90 & 0.88 \\
\hline $\mathrm{CD}(\mathrm{P}=0.05)$ & 3.07 & 2.89 & 2.98 & 2.49 & 2.61 & 2.55 \\
\hline
\end{tabular}

\begin{tabular}{|c|c|c|c|}
\hline $\mathrm{T}_{1}$-Control & T5.75\%RDF+ P-OMF@5.0qha ${ }^{-1}$ & $\mathrm{~T}_{9}-75 \% \mathrm{RDF}+\mathrm{S}-\mathrm{OMF} @ 10.0 \mathrm{qha}{ }^{-1}$ & $\begin{array}{l}\mathrm{T}_{13}-50 \% \mathrm{RDF}+\mathrm{P}-\mathrm{OMF} @ 5.0 \mathrm{qha}^{-1}+\mathrm{S}- \\
\text { OMF@5.0qha }\end{array}$ \\
\hline $\mathrm{T}_{2}-\mathbf{5 0} \% \mathrm{RDF}$ & $\mathbf{T}_{6}-75 \%$ RDF+S-OMF@5.0qha ${ }^{-1}$ & $\mathbf{T}_{10}-75 \% \mathrm{RDF}+\mathrm{P}-\mathrm{OMF} @ 10.0 \mathrm{qha}^{-1}+\mathrm{S}-\mathrm{OMF} @ 10.0 \mathrm{qha}^{-1}$ & $\mathbf{T}_{14}-50 \% \mathrm{RDF}+\mathrm{S}-\mathrm{OMF} @ 10.0 \mathrm{qha}^{-1}$ \\
\hline $\mathrm{T}_{3}-75 \% \mathrm{RDF}$ & $\begin{array}{l}\text { T }_{7}-75 \% \mathrm{RDF}+\mathrm{P}-\mathrm{OMF} @ 5.0 \mathrm{qha}^{-1}+\mathrm{S}- \\
\text { OMF@5.0qha }\end{array}$ & $\mathbf{T}_{11}-50 \% \mathrm{RDF}+\mathrm{P}-\mathrm{OMF} @ 5.0 \mathrm{qha}^{-1}$ & $\mathbf{T}_{15}-50 \% \mathrm{RDF}+\mathrm{P}-\mathrm{OMF} @ 10.0 \mathrm{qha}^{-1}$ \\
\hline $\begin{array}{l}T_{4^{-}} \\
100 \% \text { RDF }\end{array}$ & $\mathbf{T}_{\mathbf{8}}-75 \% \mathrm{RDF}+\mathrm{P}-\mathrm{OMF} @ 10.0 \mathrm{qha}^{-1}$ & $\mathbf{T}_{\mathbf{1 2}}-50 \% \mathrm{RDF}+\mathrm{S}-\mathrm{OMF} @ 5.0 \mathrm{qha}^{-1}$ & $\begin{array}{l}\mathbf{T}_{16}-50 \% \mathrm{RDF}+\mathrm{P}-\mathrm{OMF} @ 10.0 \mathrm{qha}^{-1}+\mathrm{S}- \\
\text { OMF@10.0qha }\end{array}$ \\
\hline
\end{tabular}

S-OMF-Sulphur organo mineral fertilizer

P-OMF-Phosphorus organo mineral fertilizer 
Table.3 Effect of phosphorus and sulphur organo-mineral fertilizers on apparent P and S- recovery by green gram

\begin{tabular}{|c|c|c|c|c|c|c|}
\hline \multirow[t]{2}{*}{ Treatment } & \multicolumn{3}{|c|}{ Apparent P -recovery (\%) } & \multicolumn{3}{|c|}{ Apparent S-recovery (\%) } \\
\hline & 2013-14 & 2014-15 & Pooled & 2013-14 & 2014-15 & Pooled \\
\hline$\overline{T_{1}}$ & 0.00 & 0.00 & 0.00 & 0.0 & 0.0 & 0.0 \\
\hline $\mathbf{T}_{2}$ & 1.49 & 2.90 & 2.24 & 6.94 & 5.42 & 6.18 \\
\hline $\mathbf{T}_{3}$ & 3.56 & 3.27 & 3.72 & 8.87 & 8.49 & 8.68 \\
\hline $\mathbf{T}_{4}$ & 6.34 & 3.27 & 4.84 & 10.42 & 12.29 & 11.36 \\
\hline $\mathbf{T}_{5}$ & 8.08 & 4.84 & 6.11 & 18.21 & 17.45 & 17.83 \\
\hline$\overline{T_{6}}$ & 12.09 & 5.91 & 8.59 & 28.18 & 31.29 & 29.74 \\
\hline $\mathbf{T}_{7}$ & 12.91 & 6.79 & 9.08 & 34.84 & 22.45 & 28.65 \\
\hline $\mathrm{T}_{8}$ & 14.27 & 6.61 & 9.37 & 45.66 & 31.94 & 38.80 \\
\hline$\overline{T_{9}}$ & 14.69 & 6.40 & 7.77 & 40.38 & 36.86 & 38.62 \\
\hline $\mathbf{T}_{10}$ & 16.50 & 8.02 & 10.23 & 44.90 & 40.92 & 42.91 \\
\hline$T_{11}$ & 19.70 & 18.64 & 17.89 & 44.97 & 44.42 & 44.70 \\
\hline$T_{12}$ & 21.91 & 17.70 & 17.70 & 45.09 & 44.56 & 44.83 \\
\hline $\mathrm{T}_{13}$ & 24.61 & 20.43 & 21.13 & 45.49 & 45.63 & 45.56 \\
\hline $\mathrm{T}_{14}$ & 29.72 & 21.67 & 24.52 & 46.33 & 45.44 & 45.89 \\
\hline $\mathbf{T}_{15}$ & 29.05 & 31.30 & 29.55 & 46.38 & 46.88 & 46.63 \\
\hline $\mathrm{T}_{16}$ & 34.17 & 32.76 & 33.33 & 49.95 & 49.65 & 49.80 \\
\hline SEm \pm & 0.73 & 0.90 & 0.79 & 1.65 & 1.61 & 1.63 \\
\hline $\mathrm{CD}(\mathrm{P}=0.05)$ & 2.12 & 2.59 & 2.28 & 4.78 & 4.66 & 4.74 \\
\hline
\end{tabular}

\begin{tabular}{|c|c|c|c|}
\hline $\mathbf{T}_{1}$-Control & 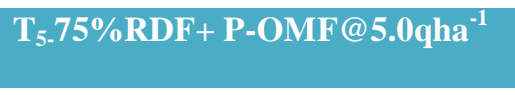 & $\mathrm{T}_{9}-75 \% \mathrm{RDF}+\mathrm{S}-\mathrm{OMF} @ 10.0 \mathrm{qha} \mathrm{a}^{-1}$ & $\begin{array}{l}\mathrm{T}_{13}-50 \% \mathrm{RDF}+\mathrm{P}-\mathrm{OMF} @ 5.0 \mathrm{qha}^{-1}+\mathrm{S}- \\
\text { OMF@5.0qha }\end{array}$ \\
\hline $\mathrm{T}_{2}-50 \% \mathrm{RDF}$ & $\mathbf{T}_{6}-75 \% \mathrm{RDF}+\mathrm{S}-\mathrm{OMF} @ 5.0 \mathrm{qha}^{-1}$ & $\mathbf{T}_{10}-75 \%$ RDF+P-OMF@10.0qha + S-OMF@10.0qha ${ }^{-1}$ & $\mathbf{T}_{14}-50 \% \mathrm{RDF}+\mathrm{S}-\mathrm{OMF} @ 10.0 \mathrm{qha}^{-1}$ \\
\hline $\mathrm{T}_{3}-\mathbf{7 5} \% \mathrm{RDF}$ & $\begin{array}{l}\text { T.7 }_{7} \text { 75\%RDF+P-OMF@5.0qha }{ }^{-1}+\mathrm{S}- \\
\text { OMF@5.0qha }\end{array}$ & $\mathbf{T}_{11}-50 \% \mathrm{RDF}+\mathrm{P}-\mathrm{OMF} @ 5.0 \mathrm{qha}{ }^{-1}$ & $\mathbf{T}_{15}-50 \% \mathrm{RDF}+\mathrm{P}-\mathrm{OMF} @ 10.0 \mathrm{qha}^{-1}$ \\
\hline $\begin{array}{l}\mathrm{T}_{4^{-}} \\
100 \% \mathrm{RDF}\end{array}$ & $\mathbf{T}_{\mathbf{8}^{-}}-75 \% \mathrm{RDF}+\mathrm{P}-\mathrm{OMF} @ 10.0 \mathrm{qha}^{-1}$ & $\mathbf{T}_{12}-50 \% \mathrm{RDF}+\mathrm{S}-\mathrm{OMF} @ 5.0 \mathrm{qha}^{-1}$ & $\begin{array}{l}\mathbf{T}_{16}-50 \% \mathrm{RDF}+\mathrm{P}-\mathrm{OMF} @ 10.0 \mathrm{qha}^{-1}+\mathrm{S}- \\
\text { OMF@10.0qha }\end{array}$ \\
\hline
\end{tabular}

S-OMF-Sulphur organo mineral fertilizer

P-OMF-Phosphorus organo mineral fertilizer 
The higher phosphorus use efficiency in green gram 23.98 (kg grain $\mathrm{kg}^{-1}$ applied $\mathrm{P}$ ) recorded with treatment $\mathrm{T}_{16}(50 \% \mathrm{RDF}+\mathrm{P}-\mathrm{OMF} @ 10.0 \mathrm{q}$ $\mathrm{ha}^{-1}+$ S-OMF@10.0q ha ${ }^{-1}$ ) (Table 2). The application of $\mathrm{P}$ and $\mathrm{S}$ organomineral fertilizers significantly increased phosphorus use efficiency of green gram by 42 and $69 \%$ over the control $\left(\mathrm{T}_{1}\right)$ in both the years. Rock phosphates can be modified and release more plant available P (Straaten, 2002). There are alternative ways that increase the agronomic efficiency of rock phosphate mainly by biological, chemical and physical means (FAO, 2004).

\section{Sulphur use efficiency}

Sulphur use efficiency in green gram varied

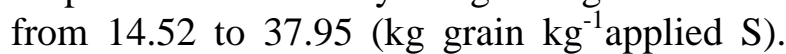
The higher sulphur use efficiency in green gram is $37.95\left(\mathrm{~kg}\right.$ grain $\mathrm{kg}^{-1}$ applied $\left.\mathrm{S}\right)$ was recorded with treatment $\mathrm{T}_{16}(50 \% \mathrm{RDF}+\mathrm{P}-\mathrm{OMF} @ 10.0 \mathrm{q}$ $\mathrm{ha}^{-1}+\mathrm{S}-\mathrm{OMF} @ 10.0 \mathrm{q} \mathrm{ha} \mathrm{h}^{-1}$ ) and lower with the control plot (Table 2). The application of $\mathrm{P}$ and $\mathrm{S}$ organomineral fertilizers significantly increased sulphur use efficiency of green gram by 42 and $69 \%$ over the control $\left(\mathrm{T}_{1}\right)$ during both the year of experimentation.

\section{Apparent phosphorus recovery (\%)}

The apparent phosphorus recovery $(\%)$ in green gram varied from 2.24 to $33.33 \%$ (Table 3 ).

The maximum apparent phosphorus recovery (\%) in green gram $33.33 \%$ was recorded in treatment $\mathrm{T}_{16}$ (50\%RDF+ P-OMF@10.0q ha ${ }^{-1}$ +S-OMF @10.0q ha ${ }^{-1}$ ). Treatment $\mathrm{T}_{13}$ and $\mathrm{T}_{14}$ at par over the rest treatment in green gram in both the year. The $\mathrm{P}$ use efficiency, apparent recovery and value cost ratio are favorably influenced by $\mathrm{P}$ application irrespective of the experimental locations (Bharathi and Poongothai 2008).

\section{Apparent sulphur recovery (\%)}

The data showed that the apparent sulphur recovery $(\%)$ in green gram varied from 6.18 to
$49.80 \%$ (Table 3). The maximum apparent sulphur recovery (\%) in green gram $49.80(\%)$ was recorded in treatment $\mathrm{T}_{16}(50 \% \mathrm{RDF}+\mathrm{P}-$ OMF@10.0q ha ${ }^{-1}+\mathrm{S}-\mathrm{OMF} @ 10.0 \mathrm{q} \mathrm{ha}^{-1}$ ). Treatment $\mathrm{T}_{13}$ and $\mathrm{T}_{14}$ at par over the rest treatment in green gram and wheat cropping sequence in both the year.

Apparent recovery of nutrient from the mineral fertilizer, estimated as the slope of the regression of plant accumulation against the rate of $\mathrm{N}$ applied and expressed as a percentage, was 65, 33 and $78 \%$ in 2000, 2001 and 2002, respectively (Zebarth et al., 2005).

Present investigation envisages that application of P and S- Organo Mineral Fertilizers @ 10.0 q ha $^{-1}$ along with $50 \%$ of recommended dose of $\mathrm{N}, \mathrm{P}$ and $\mathrm{K}$ fertilizers have resulted in higher grain yield, agronomic use efficiency and apparent recovery of nutrients by green gram of an alluvial soil of Varanasi. In this respect development of Organo-Mineral Fertilizers is one of the most alternative and important innovation technology for sustaining crop productivity and soil health.

\section{Acknowledgement}

The authors acknowledge the Head, Department of Soil Science and Agricultural Chemistry for providing necessary facilities for conducting experiment and esteemed referee for revision of manuscript whose comments and advice has greatly enhanced this article.

The first author also thanks to the UGC, New Delhi for providing fellowship during research programme.

\section{References}

Ali, Masood and Gupta, Sanjeev 2012. Carrying capacity of Indian agriculture: pulse crops. Current Science, 102 (6): 874-881.

Bharathi C. and S. Poongothai 2008Direct and Residual Effect of Sulphur on Growth, Nutrient Uptake, Yield and its Use Efficiency in Maize and Subsequent 
Green gram. Research Journal of Agriculture and Biological Sciences, 4(5): 368-372

Biswas, D.R. 2011. Nutrient recycling potential of rock phosphate and waste mica enriched compost on crop productivity and changes in soil fertility under potatosoybean cropping sequence in an Inceptisol of Indo-Gangetic Plains of India Nutr Cycl Agro ecosystem, 89:1530

Biswas, D.R. and Narayanasamy, G. 2006. Rock phosphate enriched compost: An approach to improve low-grade Indian rock phosphate. Bioresource Technology, 97: 2243-2251.

Biswas, D.R., Narayanasamy, G., Datta, S.C., Singh, G., Begum, Mamata, Maiti, Debtanu, Mishra, Amit and Basak, B.B. 2009. Changes in Nutrient Status during Preparation of Enriched Organo-mineral Fertilizers Using Rice Straw, Low-Grade Rock Phosphate, Waste Mica, and Phosphate Solubilizing Microorganism. Communications in Soil Science and Plant Analysis, 40: 2285-2307.

Kushwaha, H.S. 2007. Response of chickpea to biofertilizers, nitrogen and phosphorus fertilization under rainfed environment. Journal of Food Legumes, 20: 179-181.

Narayanasamy, G. and Biswas, DR. 1998. Phosphate rocks of India-Potentialities and constraints. Fertiliser News. 43(10): 21-28.

Patel, S.R. and Thakur, D.S. 2003. Response of Black gram (Phaseolus mungo) to levels of phosphorus and phosphate solubilizing bacteria. Annals of Agriculture Research, 24: 819-823.
Reddy, K.S., Rao, D.S., Rao, Z.P., Prasad, J.R. 2000. Effect of inclusion of varying levels of urad (Phaseolus mungo) chuni in concentrate mixtures on the nutrient utilization in native male buffaloes. Buffalo Bulletin, 19 (2): 43-47.

Saravanan, T. and Panneerselvam, P. 2014. Effect of organic manures and rock phosphate on Growth and yield of Bengal gram (Cicer areitinum L.). International Journal of Science and Nature, 5: 563566.

Singh, C.P. and Amberger, A. 1998. Organic acids and phosphorus solubilization in straw composted with rock phosphate. Bioresource Technology, 63: 13-16.

Singh, Y.P. 2004. Role of sulphur and phosphorus in Black gram production. Fertilizer News, 49: 33-36.

Yadav, K.R. 2013. Effect of phosphorus source and phosphorus solublizing microorganism on performance of mungbean (Vigna radiata (L.) Wilczek) grown in entisols. M.Sc. Thesis, Department of Agronomy, SKRAU, Bikaner.

Yadav, P.S., Kameria, P.R. and Rathore, S. 2002. Effect of phosphorus and iron fertilization on yield, protein content and nutrient uptake in Mung bean on loamy sand soil. Journal of the Indian Society of Soil Science, 50: 225-226.

Zebarth, B. J., Chabot, R., Coulombe, J., Simard, R. R., Douheret, J. and Tremblay, N. 2005. Pelletized organo-mineral fertilizer product as a nitrogen source for potato production. Canadian Journal of Soil Science, 85: 387-395.

\section{How to cite this article:}

Singh, D.K., Surendra Singh and Amitesh Kumar Singh. 2018. Effect of Phosphorus and Sulphur Organo-Mineral Fertilizers on Grain Yield, Agronomic Use Efficiency and Apparent Recovery by Green Gram (Vigna radiata L.). Int.J.Curr.Microbiol.App.Sci. 7(06): 633-641. doi: https://doi.org/10.20546/ijcmas.2018.706.073 